Persp. Teol. 39 (2007) 213-238

\title{
O [IRRENUNCIÁVEL!] PAPEL DA TEOLOGIA NOS ESTUDOS DE RELIGIÃO*
}

\author{
Adilson Schultz \\ Pouco por força podemos, \\ isso que é, por saber veio, \\ todo o mal jaz nos extremos, \\ o bem todo jaz no meio. \\ Sá de Miranda ${ }^{1}$
}

RESUMO: As análises que seguem conjugam estudos de religião e imaginário, visando apresentar sinteticamente partes relevantes do conhecimento sobre religião no âmbito da Sociologia, Antropologia, Psicologia e Teologia. A tese é que a Teologia tem um papel insubstituível no estudo do fenômeno religioso, pois só aí a religião é levada ao extremo de sua singularidade, a manifestação do divino. É a teologia que considera aquilo que difere o fenômeno religioso de qualquer outra significação imaginária, qual seja, a pertinência da revelação divina, aquilo que funda e fundamenta a religião, suas práticas, performance, ritos e discurso.

\footnotetext{
* O presente artigo é parte da Tese de Doutorado Deus está presente - o diabo está no meio: o protestantismo e as estruturas teológicas do imaginário religioso brasileiro. São Leopoldo: EST, 2004.

${ }^{1}$ Citado em S. BUARQUE DE HOLLANDA, Raizes do Brasil, 4a ed., Brasília: UNB, 1963, p. 111.
} 
Para tanto o artigo passa pelas análises clássicas de Marx, Freud, Durkheim e Castoriadis, contrapondo-as a estudiosos contemporâneos como Deleuze e Geertz, e, por fim, conjugando essas últimas com a teologia radical de Rudolf Otto.

$\mathrm{O}$ artigo propõe uma espécie de ação afirmativa teológica no estudo da religião, visando, através de uma radicalização do discurso teológico, a correção de uma situação esquizofrênica nos estudos da religião, que via de regra desconsideram a perspectiva teológica.

PAlAVRAS-CHAVE: Estudos de religião, Rudolf Otto, Teologia, Método de Ciências da Religião.

ABSTRACT: The analyses which follow join studies of religion and the imaginative, seeking to present synthetically relevant segments of knowledge about religion in the field of Sociology, Anthropology, Psychology and Theology. The thesis is that Theology has a non substitutive role in the study of religious phenomenon, since only here is religion brought to the limit of its singularity, the manifestation of the divine. It is theology which considers that which differentiates religious phenomenon from any other imaginary significance, which is the relevance of divine revelation, that which underlies religion, its practices, performance, rites and discourse.

For this purpose, the article surveys the classical analyses of Marx, Freud, Durkheim and Castoriadis, seeing them the light of contemporary thinkers such as Deleuze and Geertz and, finally, joining these with the radical theology of Rudolf Otto.

The article proposes a type of affirmative action theology in the study of religion, seeking, through a radicalization of theological discourse, the correction of a schizophrenic situation in studies of religion, which ordinarily does not consider the theological perspective.

KEY-WORDS: Study of religion, Rudolf Otto, Theology, Method of Sciences of Religion.

\title{
Introdução: A imanência e a transcendência no estudo da religião
}

\begin{abstract}
A s análises que seguem conjugam estudos de religião e imaginário, visando apresentar sinteticamente partes relevantes do conhecimento sobre religião no âmbito da Sociologia, Antropologia, Psicologia e Teologia. A tese defendida é que a Teologia tem um papel insubstituível no estudo do fenômeno religioso. É no seu universo que a religião é levada ao extremo da singularidade; é a teologia que considera aquilo que difere o fenômeno religioso de qualquer outra significação imaginária, qual seja, a pertinência da revelação divina, aquilo que funda e fundamenta a religião, suas práticas, performance, ritos e discurso.

Para tanto o artigo passa pelas análises clássicas de Marx, Freud, Durkheim e Castoriadis, contrapondo-as a estudiosos contemporâneos como Deleuze
\end{abstract}


e Geertz, e, por fim, conjugando essas últimas com a teologia radical de Rudolf Otto. Em outras palavras, o artigo propõe uma espécie de ação afirmativa teológica no estudo da religião, visando, através de uma radicalização do discurso teológico, a correção de uma situação esquizofrênica no estudo da religião que ignora ou desconsidera a teologia. O balanço dos dois campos permitirá também, ao fim, apontar os limites de ambas as perspectivas no estudo da religião.

Lançando mão de uma imagem, poder-se-ia dizer que todo o debate em torno da religião está disposto sobre uma linha estendida que tem nos seus extremos duas teorias reducionistas diametralmente opostas uma à outra, a imanente e a transcendente.

Num extremo, uma compreensão puramente teológica, que considera a religião emanação da revelação de Deus, puro e genuíno reflexo de Deus. O grande teórico contemporâneo dessa tese é Rudolf Otto e sua teoria da religião enquanto fenômeno totalmente $a$ priori, não condicionado por nada humano, nem psicológico, nem sociológico, nem filosófico-ideológico.

No outro extremo da linha, uma compreensão puramente fenomenológica, que considera a religião emanação das condições e estruturas sociais e condicionamentos psicológicos. Freud e Marx representam bem esse pólo.

No meio da linha, um ponto zero fictício que aproximaria ao máximo as duas perspectivas.

Ao longo da linha, distribuídas em inúmeros pontos dispostos ora mais à esquerda ora mais à direita do ponto zero, as inúmeras tentativas de interpretação da religião. À esquerda do ponto zero, dois grandes grupos engalfinham-se e ao mesmo tempo colaboram para consolidar o campo fenomenológico da pesquisa: a redução psicológica e a redução sociológica: ou a religião é pura manifestação de condicionamentos psicológicos, geralmente fruto de carências internas individuais, ou é pura manifestação sociológica, geralmente fruto de carências externas sociais. À direita do ponto zero, dois outros grandes grupos engalfinham-se e ao mesmo tempo colaboram para consolidar o campo teológico da pesquisa: a redução eclesiológica e apologética e a redução fenomenológica e aberta; ou a religião é aquilo que está manifesto na Igreja cristã e a revelação de Deus em Jesus Cristo; ou a religião está manifesta no seguimento que dá à revelação de Deus no mundo, também na Igreja, também em Jesus Cristo.

Imperativo para o debate e para a apreciação do fenômeno religioso é como fazer para escapar tanto do reducionismo imanente quanto do transcendente; da ilusão da autonomia absoluta do discurso religioso e da ilusão da dependência total desse discurso em relação às condições sociais ou psicológicas; da ilusão de considerar religião mero reflexo de Deus e daquela de considerá-la mero reflexo das estruturas sociais. 
A imagem da linha não deveria propor reducionismos. Não é verdade que a pesquisa teológica não leva em conta a Sociologia ou a Psicologia. Da mesma forma, não é verdade que as outras ciências jamais levem em conta a teologia. Os dois lados da linha às vezes se misturam ou se engalfinham. Todavia, é notório que o lado mais forte do debate da religião é o lado imanente. A teologia e a sua pertinente contribuição para o debate da religião, a compreensão da Revelação de Deus, estão marginalizadas - o detalhe mais cativante do debate é saber se a linha é uma reta que se esvai infinitamente em direções opostas ou se, em algum momento, os extremos se tocam, anulando o ponto zero...

\section{1 - Estudos de religião e imaginário nas Ciências Humanas}

Os estudos da religião seguem profundamente significados por Karl Marx e sua famosa descrição da religião enquanto ópio do povo: a religião é um reflexo da alienação social e econômica dos povos. Por isso mesmo, seu destino é a superação e a extinção, vinculando à superação da alienação a irrupção da sociedade justa. Em Marx, criticar a religião equivale a criticar o capitalismo que cria a condição de alienação da humanidade e engendra seus refúgios, como a religião. Isso significa que Marx não está atacando a religião em si, mas o sistema que a engendra. A religião é até, em certo sentido, positivada enquanto suspiro dos oprimidos, reflexo de um mundo sem coração; um protesto contra o mundo real de angústias, aflições, perseguições, alienação. Segundo Marx,

a religião é a teoria geral deste mundo, a sua soma enciclopédica, a sua lógica sob forma popular, o "son point d'honneur" espiritualista, o seu entusiasmo, a sua sanção moral, o seu complemento solene, a sua consolação e justificação universais. É a realização fantástica do ser humano, porque o ser humano não possui verdadeira realidade. Lutar contra a religião é pois, indiretamente, lutar contra esse mundo, de que a religião é o aroma espiritual.

A angústia religiosa é, por um lado, a expressão da angústia real e, por outro, o protesto contra a angústia real. A religião é o suspiro da criatura oprimida, a alma de um mundo sem coração, tal como é o espírito de condições sociais, de que o espírito está excluído. Ela é o opium do povo.

A abolição da religião enquanto felicidade ilusória do povo é uma exigência que a felicidade real formula. Exigir que renuncie às ilusões acerca da sua situação é exigir que renuncie a uma situação que precisa de ilusões. A crítica da religião é, pois, em germe, a crítica deste vale de lágrimas de que a religião é a auréola ${ }^{2}$.

\footnotetext{
${ }^{2}$ K. MARX, em "Crítica da filosofia do direito de Hegel”, citado em I. LESBAUPIN, "Marxismo e religião", in F. TEIXEIRA, Sociologia da Religião, Petrópolis: Vozes, 2003, p. 13-35, aqui $34-35$.
} 
No extremo imanente dos estudos da religião está a reivindicação da dependência psicológica do discurso religioso, formulada pelo psicanalista Sigmund Freud. Para ele a religião é uma ilusão a ser superada. Seus ataques à religião baseiam-se não na crítica ao sistema alienante, como em Marx, mas na crítica ao crente - ou paciente - alienado. Ainda que reconheça sua força, a religião é uma ilusão - e mais do que isso: uma falsa ilusão ${ }^{3}$.

[As idéias religiosas] são ilusões, realizações dos mais antigos, fortes e prementes desejos da humanidade. $\mathrm{O}$ segredo de sua força reside na força desses desejos. (...) Ilusão não é a mesma coisa que um erro. (...) O que é característico das ilusões é o fato de derivarem de desejos humanos (...) As ilusões não precisam ser necessariamente falsas, ou seja, irrealizáveis ou em contradição com a realidade. (...) Todas elas [as crenças religiosas] são ilusões e insuscetíveis de prova. Ninguém pode ser compelido a achá-las verdadeiras, a acreditar nelas. Algumas (...) [são] delírios ${ }^{4}$.

Freud associa a religião a um estágio infantil do desenvolvimento humano, que teria que ser superado. A impressão de desamparo na infância prolonga-se na vida adulta: o desejo de um pai manifesta-se no desejo de um pai todo-poderoso. A providência divina garante proteção, justiça, fidelidade, amor, como um pai. Os complexos e traumas surgidos na infância em torno da figura do pai são transferidos para um sistema universal que, em si, é extremamente consolador, mas tem um ingrediente patológico, pois não permite ao ser humano viver plenamente como ser autônomo. A essa altura, então, o argumento de Freud contra a religião já está consolidado como crítica ao crente: "A religião é comparável a uma neurose da infância. (...) A humanidade superará essa fase neurótica, tal como muitas crianças evolvem de suas neuroses semelhantes" ${ }^{\prime 5}$. Religião e fé não passam de manifestação de problemas psicopatológicos. Pessoas fracas é que necessitam de religião ${ }^{6}$.

\footnotetext{
${ }^{3}$ S. FREUD, O futuro de uma ilusão, Rio de Janeiro: Imago, 1997, especialmente pp. 4853.

${ }^{4}$ S. FREUD, O futuro de uma ilusão, op. cit., pp. 48-51.

${ }^{5}$ S. FREUD, O futuro de uma ilusão, op. cit., p. 82. Freud chega ao extremo de sua compreensão de religião ao referir uma metáfora: às crianças é dito que os bebês vêm através de uma cegonha. Certamente elas não estão preparadas para saber como o bebê de fato vem, mas não há como evitar que, mais tarde, quando ela descobrir como as coisas são, que ela se sinta enganada. As crianças vivem de uma ilusão, que não é necessariamente um erro. Mas as crianças um dia superarão essa ilusão; precisam superar. Com a religião aconteceria ou deveria acontecer a mesma coisa. Cf. S. FREUD, O futuro de uma ilusão, p. 71. Aqui, aliás, abre-se a crítica a Freud devido à sua compreensão doentia da infância. A criança é sempre uma espécie de adulto mal formado; um adulto ignorante. ${ }^{6}$ Para uma análise mais profunda da compreensão freudiana de religião, cf. G. FILORAMO / C. PRANDI, As ciências das religiões, São Paulo: Paulus, 1999, pp. 173-179. Para uma crítica voraz e análise das principais obras de Freud considerando sua negação da potência religiosa a priori, cf. R. GIRARD, A violência e o sagrado, $2^{\text {a }}$ ed., São Paulo: Paz e Terra, 1990 - por exemplo, p. 269: "Para escapar definitivamente às ilusões do humanismo, uma única condição necessária, mas justamente a única que o homem
} 
Como se vê, em Marx e Freud a religião e qualquer significação imaginária é compensação à precariedade da vida ou à falta de sentido. Ou o imaginário é fruto de um sistema externo das consciências - Marx -, baseado em condicionamentos sócio-históricos específicos, ou é fruto das pulsões e do recalcamento individuais - Freud. A fonte criadora do imaginário é ora a cultura, ora a psique; ora a sociedade; ora o indivíduo. Em oposição ao mundo real e sua aspereza, o imaginário cria imagens compensatórias; a religião cria o céu como forma compensatória ou um prêmio para as agruras da vida. Assim como cria o belo da arte para resistir à realidade bruta, o ser humano cria Deus, e cria inclusive a crença de que Deus conduz a história com propósito transcendental, compensando a sensação de caos do dia-a-dia das pessoas. Esta tem sido, aliás, a interpretação recorrente do fenômeno pentecostal brasileiro: a pessoa pobre, sem uma vida digna, vive a partir de um imaginário construído e oferecido por uma instituição que apregoa e convence a pessoa de que ela é rica em Jesus, e ali encontra forças para sobreviver à desgraça. Aí a religião vira um narcótico, algo que, consciente ou inconscientemente, está aí à nossa disposição - daí também as compreensões narcotificantes de religião.

Mas há outras considerações sociológicas e psicológicas da religião para além de Freud e Marx: seguindo a linha imanente dos estudos da religião, talvez seja justamente o fundador da sociologia, Émile Durkheim, quem está numa posição mais ambígua. É ele quem mais veementemente ataca a procedência e o conteúdo divino da religião, mas é ele também quem mais reconhece sua força enquanto significação central de qualquer sociedade. De forma nenhuma a religião é ilusão ou algo a ser superado; muito pelo contrário: para Durkheim, a religião é a responsável pela coesão social; sem ela, a sociedade simplesmente não existiria. A religião necessariamente sofre transformações ao longo do tempo e de acordo com a cultura,

moderno recusa-se a preencher: o reconhecimento da dependência radical da humanidade em relação ao religioso. É bastante evidente que Freud não está disposto a preencher esta condição". Para o contraponto em Jung, sobretudo reconhecendo o caráter profundo contido nos valores do patrimônio religioso da humanidade, opondo o inconsciente freudiano à experiência arquetípica, cf. FILORAMO / PRANDI, As ciências das religiões, op. cit., pp. 179-184. Para uma crítica sociológica mais refinada a Freud e ao reducionismo psicológico no estudo da religião, cf. E. TROELTSCH, El carácter absoluto del cristianismo, Salamanca: Síguime, 1979, especialmente pp. 193ss: "Muchos son de la opinión de que la ciencia general de la religión tiene propiamente su centro de gravedad en la psicología de la religión de los antropólogos y de que todo lo demás no es más que una ramificación y un eco de la religión primitiva; la religión sería un producto de la psique humana primitiva con su visión de las cosas que lo personifica todo y lo refiere a intereses personales. (...) Esto es justamente positivismo y no empirismo real y auténtico. No es un análisis de la religión, sino un enjuiciamiento de aquello que la religión tiene de valor y de verdad a partir de una determinada concepción del mundo, no una psicología de la religión, sino una argumentación en contra de la religión, basada en puntos de vista psicológico-antropológicos". 
mas jamais está ausente ou desaparecerá7; é algo "essencial e permanente" bolos particulares nos quais o pensamento religioso sucessivamente se envolveu"9. "Rompendo com a tradição da época que considerava os fenômenos religiosos como um tecido de superstições, das quais os homens se libertavam desenvolvendo seus conhecimentos, Durkheim mostra que o fato religioso, ao contrário, é uma das bases essenciais da socialidade ${ }^{\prime 10}$. Contrapondo-se à ignorância científica em relação à religião - ele escreve em 1912! -, comenta: "A religião existe, é um sistema de fatos dados; em uma palavra, é uma realidade. Como poderia a ciência negar uma realidade?"11

Para Durkheim, religião não pode ser confundida com ideologia. A religião não tem apenas papel ideológico social. Religião não tem a ver apenas com idéias, mas, sobretudo, com força: a religião dá a força para viver.

A religião, com efeito, não é somente um sistema de idéias, é antes de tudo um sistema de forças. $\mathrm{O}$ homem que vive religiosamente não é somente o homem que se representa o mundo de tal ou tal maneira, que sabe o que outros ignoram; é antes de tudo um homem que experimenta um poder que não se conhece na vida comum, que não sente em si mesmo quando não se encontra em estado religioso. (...) São as forças que levantam montanhas. (...) Quando um homem vive da vida religiosa, ele pensa participar de uma força que o domina mas que, ao mesmo tempo, o sustenta e o eleva acima de si próprio ${ }^{12}$.

${ }^{7}$ É. DURKHEIM, As formas elementares da vida religiosa, São Paulo: Paulinas, 1979, p. 477.

${ }^{8}$ É. DURKHEIM, As formas elementares da vida religiosa, op. cit., p. VI.

${ }^{9}$ É. DURKHEIM, As formas elementares da vida religiosa, op. cit., p. 472.

${ }^{10}$ M. MAFFESOLI, texto de apresentação do livro É. DURKHEIM, As formas elementares da vida religiosa: São Paulo: Paulinas, 1979.

${ }^{11}$ É. DURKHEIM, As formas elementares da vida religiosa, op. cit., p. 476. Rubem Alves, um dos grandes teóricos durkheiminianos da religião, radicaliza a crítica à ignorância científica do dado religioso: "A persistência do fato religioso, contrária a todas as previsões teóricas, implica numa crítica radical à metafísica inconsciente que rege o pensamento científico. Porque enquanto a ciência, com sua dedicação confessada ao ideal de objetivismo, e à conseqüente identificação de normalidade psíquica com ajustamento, pressupõe, a priori, que o real é a verdade, a religião, das profundezas da sabedoria inconsciente da própria vida, conclui que o absurdo não são os valores utópicos, mas a própria situação humana donde eles emergem. Assim parece-me que a religião, mesmo nas suas formas mais 'alienadas', contém uma crítica do real que a ciência, prisioneira de sua própria metafísica, não tem condições para transcender. Até agora a ciência tem realizado uma tarefa muito salutar de desmitologizar a religião. Não haverá a possibilidade inversa, de que a religião abra caminhos para a desmitologização da ciência?” (R. ALVES, $O$ suspiro dos oprimidos, $5^{\text {a }}$ ed., São Paulo: Paulus, 2003, p. 100).

${ }_{12}$ Apud P. SANCHIS, “A contribuição de Émile Durkheim”, in F. TEIXEIRA, Sociologia da Religião, op. cit., pp. 33-66, aqui pp. 41-42. 
Por isso a religião não cumpre apenas $\mathrm{u} \mathrm{m}$ papel social. Ela tem também poder sobre o indivíduo - ou melhor, ela empodera o crente.

A religião supõe a ação de forças sui generis, que elevam o indivíduo acima dele mesmo, que o transportam para um meio distinto daquele no qual transcorre sua existência profana, e que o fazem viver uma vida muito diferente, mais elevada e mais intensa. $\mathrm{O}$ crente não é somente um homem que vê, que conhece coisas que o descrente ignora: é um homem que pode mais $^{13}$.

Diante dessa compreensão Durkheim compõe um conceito de religião enfatizando justamente o papel de articuladora da sociedade. A palavrachave de seu conceito é reunir ${ }^{14}$. Religião é "um sistema solidário de crenças e de práticas relativas a coisas sagradas, isto é, separadas, proibidas, crenças e práticas que reúnem numa mesma comunidade moral, chamada igreja, todos aqueles que a elas aderem" ${ }^{\prime 15}$.

O pensador contemporâneo mais atento à importância da religião é Cornelius Castoriadis. Para ele, a religião é aquilo que dá sentido à vida sem sentido. Entende que a religião não apenas dá sentido, mas ela mesma é a responsável pela falta de sentido; ou seja: ela cria o problema e oferece o antídoto. A religião é a instituição da errância da vida e a sua própria solução; criadora do caos e sua organizadora; anunciadora do Abismo e a construtora de pontes sobre ele, anunciadora e formuladora tanto do desespero quanto do tranqüilizante. A religião é um simulacro da realidade. $\mathrm{Na}$ incapacidade de o ser humano aceitar a errância da vida, ele anuncia a sua errância para domesticá-la. Dar sentido à vida pode ser sinônimo de recobrir o abismo da vida. A religião é a forma que a sociedade encontra para dizer que ela não é o fim de si mesma; que há algo além dela.

A definição de religião de Castoriadis elucida isso de forma brilhante:

A religião dá nome ao inominável, representação ao irrepresentável, lugar ao não localizável. Ela realiza e satisfaz, simultaneamente, a experiência do Abismo e a recusa a aceitá-lo, circunscrevendo-o - pretendendo circunscrevêlo -, dotando-o de uma ou mais figuras, designando os lugares que ele habita. (...) Os momentos que ele privilegia, as pessoas que o encaram, as

\footnotetext{
${ }^{13}$ É. DURKHEIM, "O problema religioso e a dualidade da natureza humana”, Religião e Sociedade $\mathrm{n}^{\circ} 2$ (1977) 1-27, aqui p. 2.

${ }^{14}$ Uma teoria [psico(?)-]sociológica que amplia essa intuição e que mereceria mais atenção da teologia dado o respeito que tem pela fé é aquela apresentada por P. BERGER, $O$ dossel sagrado, São Paulo: Paulinas, 1985, pp. 30ss: a religião atua para preservar o nomos, preservar da anomia. A religião garante que a vida coletiva ou individual não se perca no caos. O nomos constitui-se enquanto uma espécie de escudo de representações, regras, ritos e leis contra o caos. Respeitando o que a religião diz, tudo ficará bem, evitarse-á que o mundo se perca ou fique sem sentido.

${ }^{15}$ É. DURKHEIM, As formas elementares da vida religiosa, op. cit., p. 32.
} 
palavras e os textos que o revelam. A religião é, por excelência, a apresentação/ocultação do $\operatorname{Caos}^{16}$.

A religião é, a um tempo, apresentação e ocultação do Abismo. O Abismo é anunciado, presentificado na e pela religião - e, ao mesmo tempo, está essencialmente oculto. Assim por exemplo, a Morte no cristianismo: presença obsessiva, interminável lamentação - e, simultaneamente, negação absoluta, já que essa Morte na verdade não é morte, mas acesso a outra vida. $\mathrm{O}$ sagrado é o simulacro instituído do Abismo: a religião confere ao Abismo uma figura ou figuração - que é apresentado como Sentido último e, ao mesmo tempo, como fonte de todo sentido ${ }^{17}$.

Como a religião consegue tamanha façanha? A base do discurso do simulacro está na crença da instituição transcendente da sociedade e da ordem do mundo, conseqüentemente da religião. A solução social para a falta de sentido é transferir sua auto-instituição para fora, para a transcendência ${ }^{18}$. Castoriadis criticará a religião justamente aí: nada tem origem transcendente; a religião e a sociedade são sempre auto-instituição. Num procedimento análogo ao de Marx, ataca a religião para atacar a ilusão da sociedade. Ao dizer que existe um fundamento extra-social para a religião, a própria religião cria a ilusão, e dela vive. Castoriadis concluirá com uma crítica ácida aos crentes: "Não tenho necessidades de simulacros e minha modéstia faz-me crer que, a esse respeito, aquilo que é possível para mim é possível também para os outros"19.

Mas também Castoriadis não deixa de reconhecer o papel importante da religião como instituinte - Durkheim diria coesão social - da sociedade. Reconhece na religião o papel de amparar as angústias humanas. Finalmente, numa instigante formulação, ainda que considerando a religião como auto-instituída, criação essencialmente humana, ele relativiza a compreensão sociológica corrente que opõe criação humana a criação divina. Seriam as religiões simples obras humanas?

Tudo depende de saber o que se entende por isso. Será que o homem é "simplesmente humano"? Se o fosse, ele não seria homem, não seria nada. Cada um de nós é um poço sem fundo, e esse Sem-Fundo está, tudo leva a crer, aberto sobre o Sem-Fundo do mundo. Nos períodos normais, nós nos agarramos à beira do poço, na qual passamos a maior parte de nossa vida. (...) O sagrado é o simulacro instituído do Sem-Fundo ${ }^{20}$.

Seguindo esta linha de positivização da religião e do imaginário os estudos da religião encontram a obra de Gilbert Durand. Para ele as significações

${ }^{16}$ C. CASTORIADIS, As encruzilhadas do labirinto II, Rio de Janeiro: Paz e Terra, 1987, p. 387.

${ }^{17}$ C. CASTORIADIS, As encruzilhadas do labirinto II, op. cit., p. 427.

${ }^{18}$ Cf. C. CASTORIADIS, As encruzilhadas do labirinto II, op. cit., p. 392.

${ }^{19}$ C. CASTORIADIS, As encruzilhadas do labirinto II, op. cit., p. 259.

${ }^{20}$ C. CASTORIADIS, As encruzilhadas do labirinto II, op. cit., p. 259. 
imaginárias - inclusive a religião - movem a sociedade e as pessoas. Segundo ele, nem só as frustrações ou os desejos precisam ser imaginados e simbolizados, mas também todas as conquistas e as idéias ${ }^{21}$. Significações imaginárias são produções, e não reações a aspectos negativos. As significações imaginárias são responsáveis não só pelos sentimentos, mas também pelas estruturas mais formais de pensamento ${ }^{22}$. O mundo imaginário e a religião não são o reflexo de mentalidades infantis ou doentias, mas o início de todos os impulsos, inclusive os racionais. As imagens criadas não são meros recursos didáticos, apoiadores, mas reais fontes criativas do pensamento. Aquilo que convencionalmente denominou-se recalcamento infantil, o abandono progressivo das metáforas/imagens em prol do racional, pode ser visto como um empobrecimento do conhecimento, e não um avanço ${ }^{23}$. Além do protagonismo da imagem na estrutura do pensamento, resta que verdades subjetivas, imaginárias - como a religião -, muitas vezes são mais relevantes para o pensamento do que fenômenos observávei ${ }^{24}$. Aquilo que é normalmente considerado fantasia, erro, perda de tempo, falso, é muito mais comum no mundo do que as frágeis verdades comprovadas ${ }^{25}$. Por isso Durand reivindica que "uma pedagogia da imaginação se impõe ao lado da cultura física e do raciocínio"26. A partir dessa reivindicação é que Durand construirá seu conceito de imaginário enquanto encruzilhada,"denominador fundamental onde se vêm encontrar todas as criações do pensamento humano (...); conjunto de imagens e relações de imagens que constitui o capital pensado do homo sapiens" ${ }^{\prime 27}$.

Em seguida Durand falará de trajeto antropológico ${ }^{28}$, termo com o qual equaliza todos os binômios que envolvem o estudo do imaginário ou de suas significações - real-irreal, instituinte-instituído, cultura-psique, útilinútil, indivíduo-sociedade, sociedade-imaginário, material-espiritual, transcendente-imanente: o imaginário e suas significações, inclusive as religiosas: é no vínculo dos dois domínios que acontece a significação imaginária e se consolida o imaginário. O imaginário formado seria um encontro, um caldo, o equilibrador, uma corda que liga os dois mundos, misturando o racional e o imaginativo.

Seguindo Durand, o psicanalista Gilles Deleuze acrescenta que o imaginário não é nem o real nem o irreal, mas justamente a "indiscernibilidade

\footnotetext{
${ }^{21}$ Cf. G. DURAND, As estruturas antropológicas do imaginário, $3^{\mathrm{a}}$ ed., São Paulo: Martins Fontes, 2002, pp. 392-393.

${ }^{22} \mathrm{O}$ termo é de G. DURAND, As estruturas antropológicas do imaginário, op. cit., p. 27.

${ }^{23}$ G. DURAND, As estruturas antropológicas do imaginário, op. cit., p. 394.

${ }^{24}$ G. DURAND, As estruturas antropológicas do imaginário, op. cit., p. 395.

${ }^{25}$ G. DURAND, As estruturas antropológicas do imaginário, op. cit., p. 427.

${ }^{26}$ G. DURAND, As estruturas antropológicas do imaginário, op. cit., p. 430.

${ }^{27}$ G. DURAND, As estruturas antropológicas do imaginário, op. cit., p. 18.

${ }^{28}$ G. DURAND, As estruturas antropológicas do imaginário, op. cit., pp. 41 e 395.
} 
entre o real e o irreal. Os dois termos não se correspondem, eles permanecem distintos, mas não cessam de trocar sua distinção. (...) O imaginário é esse conjunto de trocas" 29 . O processo de criação e instalação das significações imaginárias é elucidado pela distinção que Castoriadis faz entre imaginário e significações imaginárias: imaginário seria o produto final de uma série de significações imaginárias agrupadas ${ }^{30}$. A teoria do trajeto antropológico de Durand vale também aqui: paradoxalmente, é o imaginário, em sua totalidade, que permite a criação das significações; que, por sua vez, compõem o que se pode denominar coletivamente imaginário ${ }^{31}$. As significações imaginárias podem ser entendidas como produções ${ }^{32}$ de uma multiplicidade infinita de fontes ou vetores ${ }^{33}$, que, no seu conjunto, compõem a capacidade criativa do imaginário. Daí que as significações imaginárias nem sempre são conseqüência $d e$, fuga de, compensação $a . . . \mathrm{O}$ imaginário "tem que ser pensado, não como uma réplica irreal de um mundo real (...). Temos que pensá-lo como posição primeira, inaugural, irredutível (...), tal como se manifesta cada vez numa sociedade dada" ${ }^{34}$.

Seguindo os passos de Gilbert Durand, o antropólogo Clifford Geertz talvez seja quem mais se aproxima de uma teoria mista no estudo da religião, conjugando o rigor antropológico à referência da experiência religiosa e assim se esforçando para preservar o que de fato significa a religião para o crente: salvação. Seu conceito de religião conjuga a função cultural da religião enquanto criadora de uma estrutura de mundo - dando coesão, diria Durkheim - e seu papel de fornecer sentido religioso, mas não qualquer sentido, e sim salvação: Religião é

(1) um sistema de símbolos que atua para

(2) estabelecer poderosas, penetrantes e duradouras disposições e motivações nos homens através da

(3) formulação de conceitos de uma ordem de existência geral e

(4) vestindo essas concepções com tal aura de fatualidade que

(5) as disposições e motivações parecem singularmente realistas ${ }^{35}$.

${ }^{29}$ G. DELEUZE, Conversações, Rio de Janeiro: Editora 34, 1992, pp. 84-86.

${ }^{30}$ C. CASTORIADIS, A instituição imaginária da sociedade, $2^{\mathrm{a}}$ ed., Rio de Janeiro: Paz e Terra, 1986, pp. 169-170.

${ }^{31}$ Para mais detalhes sobre o imaginário, cf. C. CASTORIADIS, As encruzilhadas do labirinto II, op. cit., especialmente pp. 373-393 - instituição da sociedade e religião, e pp. 225-43 - o imaginário: a criação no domínio social-histórico; mas também pp. 247-267 uma interrogação sem fim; e ainda pp. 2-19 - prefácio. Também cf. C. CASTORIADIS, A instituição imaginária da sociedade, especialmente pp. 385-418 - As significações imaginárias sociais, e ainda pp. 139-200 - A instituição e o imaginário.

${ }^{32}$ F. GUATTARI, Caosmose, São Paulo: Editora 34, 1992, p. 33.

${ }^{33}$ F. GUATTARI, Caosmose, op. cit., p. 33.

${ }^{34}$ G. DELEUZE, Conversações, op. cit., p. 86.

${ }^{35}$ C. GEERTZ, A interpretação das culturas, Rio de Janeiro: Zahar, 1978, p. 67. 
Percebe-se em seu conceito que a religião age como, serve para, exprimindo aquilo que no religioso emerge da experiência individual ou social - de acordo com Freud e Durkheim -, mas ela também projeta o funcionalsocial para além da experiência, e veste essas concepções de uma extrema significância para além do real. A religião certamente ordena a experiência do fiel no mundo, mas também permite a vida dentro de um horizonte de sentido que justifica o todo, unindo o vivido ao imaginado. E é justamente aí, tratando do significado, sobretudo da questão do mal, que Geertz se dá conta da importância da questão transcendente que funda a religião: não basta apaixonar-se por um sistema religioso, não basta considerar que ele explica o mundo, ou que ele expresse a formulação de conceitos e ordens da existência: o fiel vê a religião como "símbolos de algumas verdades transcendentais" ${ }^{\prime \prime 3}$. Daí que se depreende que o ponto-chave na definição de Geertz é a frase "vestindo essas concepções com uma tal aura de fatualidade que parecem reais". Isso significa que a religião tem como base a aceitação prévia - uma fé - de uma realidade que transforma a experiência ${ }^{37}$. Certamente a existência de dor, sofrimento, dos fenômenos naturais, dos mistérios, do não explicado, do mal, enfim, tudo o que diz respeito ao problema do significado,

é uma das coisas que impulsiona os homens para a crença em deuses, demônios, espíritos, princípios totêmicos ou a eficácia espiritual do canibalismo (...) Mas essa não é a base onde repousam tais crenças, e sim seu campo e aplicação mais importante. (...) Justificamos uma crença religiosa como um todo fazendo referência à autoridade. (...) Não cultuamos a autoridade, mas aceitamos a autoridade. (...) O axioma básico subjacente naquilo que poderíamos talvez chamar de "perspectiva religiosa" é o mesmo em todo lugar: aquele que tiver de saber precisa primeiro acreditar ${ }^{38}$.

A religião cria motivações; agencia a salvação divina; não é apenas reflexo. Sem esse conceito metafísico da salvação a definição de religião de Geertz parece se desmontar. A questão não é só o significado, o existencial, mas o soteriológico, o transcendente. Daí sua insistência em diferenciar na religião o ethos - conjuntos de disposições e motivações - e a visão de mundo - imagem da ordem cósmica. De um lado ela representa o estilo de vida; de outro, estrutura ou dá sentido ao estilo ${ }^{39}$.

É justamente essa distinção e este $e$ que ele aplicará ao estudo do rito como lugar onde se encontram as disposições e motivações induzidas pelos símbolos sagrados nas pessoas $e$ as concepções gerais da ordem da existência formuladas; o rito como aquilo que funde $\mathrm{e}^{40} \mathrm{o}$ ethos e a visão de mundo,

${ }^{36}$ C. GEERTZ, A interpretação das culturas, op. cit., p. 72.

${ }^{37}$ C. GEERTZ, A interpretação das culturas, op. cit., p. 80.

${ }^{38}$ C. GEERTZ, A interpretação das culturas, op. cit., p. 81 - grifo meu.

${ }^{39}$ C. GEERTZ, A interpretação das culturas, op. cit., p. 95.

${ }^{40}$ C. GEERTZ, A interpretação das culturas, op. cit., p. 96. 
numa estrutura circular ${ }^{41}$. O rito revela a ultimicidade e a prioridade do que é sagrado na vida do fiel, em detrimento do que é imanente. "Celebrando o rito, a comunidade descobre que a estrutura social é puro blefe, uma mentira nobre ou ignóbil, uma construção social artificial da realidade. A verdadeira realidade é a antiestrutura" ${ }^{\prime 2}$. O que importa mesmo é a religião, e não o mundo.

É justamente o fato de colocar atos íntimos, banais, em contextos finais que torna a religião socialmente tão poderosa (...). Ela altera, muitas vezes radicalmente, todo o panorama apresentado ao senso comum, altera-o de tal maneira que as disposições e motivações induzidas pela prática religiosa parecem, elas mesmas, extremamente práticas, as únicas a serem adotadas com sensatez, dada a forma como são as coisas reais ${ }^{43}$.

\section{2 - Rudolf Otto: uma abordagem radicalmente teológica no estudo da religião}

Um deus que compreendemos não é Deus. Tersteegen $^{44}$

Por mais que se aproxime do ponto zero da linha dos estudos da religião referida na introdução, a teologia não fica inteiramente satisfeita com as teorias sociológicas, antropológicas e psicológicas. Para a teologia, a religião tem um aspecto transcendente na sua natureza e na sua origem, e a estuda considerando seu elemento fundante, Deus e sua Revelação. Certamente a teologia não desconhece ou ignora os estudos das ciências sociais, tampouco exige delas mais do que certamente querem ou podem oferecer, mas ela não deixa de questionar essas ciências quando se apresentam como última ou única verdade. Questiona também quando elas relativizam a própria religião e sua importância como algo a ser superado ou em fase de superação - as teorias de secularização estão aparentemente muito distantes do Brasil e do imaginário religioso ${ }^{45}$. A teologia questiona, sobretudo,

\footnotetext{
${ }^{41}$ C. GEERTZ, A interpretação das culturas, op. cit., p. 103.

${ }^{42}$ A.N. TERRIN, Antropologia e horizontes do sagrado, São Paulo: Paulus, 2006, p. 71 em referência a V. TURNER, $O$ processo ritual.

${ }^{43}$ C. GEERTZ, A interpretação das culturas, op. cit., p. 89.

${ }^{44}$ Apud R. OTTO, Lo santo, Madrid: Alianza Editorial, 2001, p. 36. No original Tersteegen diz "Ein begriffener Gott ist kein gott". O verbo greifen que está na raiz de begriffener tem também sentido físico de pegar ou captar.

${ }^{45} \mathrm{~A}$ crítica às teorias da secularização brotou de dentro da própria sociologia, como em P. BERGER, "A dessecularização do mundo", Religião e Sociedade n ${ }^{\circ} 21$ (2001) 16ss, que atribui essa crítica à religião - e à teologia - a alguns poucos mas influentes bolsões secularizados do mundo, como a Europa ocidental, a elite internacional, e uma certa subcultura acadêmica, todos estratos muito influentes na definição da realidade oficial.
} 
aquelas interpretações que parecem ter estacionado as reflexões em Marx e Freud, hoje quase que ligadas ao senso comum, não acompanhando o sensível desenvolvimento da antropologia, da psicologia e da sociologia.

Justamente frente a esses reducionismos é que se coloca a contribuição que vem a seguir, como uma espécie de ação afirmativa teológica contra as tentativas de reduções imanentes no estudo da religião. Será apresentada uma teoria de interpretação do fenômeno religioso que talvez esteja entre as mais estigmatizadas ou ignoradas, não só pelas ciências em geral, mas, sobretudo, pela própria teologia. Trata-se da teoria do a priori religioso do teólogo e historiador das religiões Rudolf Otto. Formulada justamente quando irrompia a sociologia e quando Freud assentava as bases de suas teorias da ilusão religiosa, Otto reivindica o caráter apriorístico de qualquer fenômeno religioso, a relevância do aspecto divino em sua fundação.

Segundo Otto, o discurso religioso é autônomo das condições sociais e psicológicas, totalmente criado e dado por Deus. A religião é um fenômeno a priori, anterior ao sentimento, à razão e à experiência codificada ou determinada socialmente. Não há nada humano que a explique ou justifique. Ela não surge da sociedade ou da psique humana e seus conflitos; ela se manifesta por revelação divina. Seus fundamentos não são estruturas e condicionamentos históricos ou sociais, mas o numinoso, a divindade, o santo. Por isso a religião não pode ser vista como espelho do mundo. Ela é um fenômeno essencialmente criador. Ela cria as significações que nos mantêm vivos. Ela é fonte de esperança em Deus. Ela é aquilo que diz que a realidade não é apenas aquilo que é, mas aquilo que poderia ser segundo os planos de Deus. Ela não é espelho, mas a própria imagem.

Otto reivindica que a religião precisa ser estudada também a partir daquilo que ela tem de não-racional. O Divino é uma entidade composta de elementos racionais e não-racionais. Apesar dos condicionais racionais serem aqueles que estão manifestos e perceptíveis, o fundamento último da religião e da divindade é o irracional. A categoria teológica que melhor expressa o sentido último da religião, seu fundamento, é o Numem, um termo que eleva a divindade para além de seus condicionamentos racionais, tudo o que diz respeito a doutrinas, moral, razão, manifestações psicológicas. A forma do Numem é ser essencialmente mistério. Suas qualidades são ser tremendo e fascinante a um só tempo, repulsivo e atraente, engendra temor e fascínio no crente. O Numem é o mysterium tremendum et fascinans.

Ainda que possa ser percebido apenas através do sentimento religioso, o Numem é um fenômeno totalmente a priori, ou seja, não condicionado psicológica ou socialmente, totalmente heterogêneo ${ }^{46}$. O santo, tanto em

\footnotetext{
${ }^{46}$ Para entender o a priori de Otto há que considerar também sua opção teórica pela fenomenologia. Ao propor a volta ao objeto numinoso, Otto fazia coro com os cientistas de sua época que reivindicavam a volta ao objeto, à coisa em si - cf. B.O. BIRCK, $O$ sagrado em Rudolf Otto, Porto Alegre: EDIPUCRS, 1993, p. 126ss: Otto se apóia na
} 
seu elemento racional quanto irracional, "é uma categoria para e a priori. Esta é uma afirmação que temos que manter com todo rigor frente a todo sensualismo e todo evolucionismo" ${ }^{\prime 47}$. O numinoso é a priori - não se deduz de outros sentimentos. "A religião começa consigo mesma"48. Ora: se o fundamento da religião é o Numem, e esse não nasce na cultura ou na psique, logicamente está dado que a religião é um fenômeno a priori.

Se ele é a priori e totalmente misterioso, como é possível que seja percebido? Através do sentimento religioso. A percepção sensível do Numem o sentimento religioso ou a emoção religiosa - nascem do sentimento de criatura - o ser humano se sente "um nada" e some diante d'Aquele que está sobre toda criatura. Não é um sentimento de dependência; não é um sentimento de ter sido criado, mas de ser pobre criatura ante a grandeza de Deus. O sagrado é o senso do Numem, e brota na pessoa como sentimento de criaturalidade - Kreaturgefühl. O senso do Numem é o momento de objetivação do sagrado, e o sentimento de ser criatura é o momento de subjetivação e de apropriação. Tudo no sagrado é senso e sentimento. O sagrado não tem estrutura, é indefinível. "É definitivamente essa

fenomenologia de Edmund Husserl - ainda que Otto não a cite -, que se opõe ao Idealismo e à psicologia. Husserl está propondo a volta às coisas mesmas, à forma como elas se manifestam à nossa consciência. O idealismo e a psicologia diziam que tudo, até o pensar, o imaginar e o sentir são fenômenos psíquicos. Frente a ela Husserl propõe a "intencionalidade da consciência: A consciência tem uma estrutura intencional, ou seja, não há visão sem algo visto, não há imaginação sem algo imaginado e não há pensar sem algo pensado. Portanto, existe uma distinção entre o ato de pensar, como fenômeno psíquico, e o pensamento como conteúdo (fenômeno) do pensar. (...) O pensar é um ato psíquico (empírico), que aparece e desaparece. Mas o pensamento não é um objeto real, temporal; é um objeto ideal, não temporal" - p. 130. Por isso, a filosofia e a religião devem ser fenomenológicas, ou seja, encontrar seu fundamento verdadeiro no reino das idealidades, das essências, dos fenômenos puros.

Disso resulta o caráter a priori de Otto: Há uma distinção entre o ato de crer, como fenômeno psíquico, e o ato como conteúdo (fenômeno) do crer, aquilo que é crido - o Numem, completamente a priori, totalmente puro, fora do psíquico. O sentimento religioso é algo empírico, psicológico, e em si não serve para fundamentar um conhecimento do sagrado. A essência da religião não está num sentimento de dependência, como nos psicologismos de Schleirmacher. O fundamento da religião não é algo negativo, mas uma realidade positiva, o Numem - Cf. B.O. BIRKC, O sagrado em Rudolf Otto, op. cit., p. 129. Não há visão sem algo visto. Não há fé sem algo numinoso! Daí que a religião se prova por si mesma. $\mathrm{O}$ ato de crer é um fenômeno psíquico, mas a fé é o conteúdo, o fenômeno do crer. O crer é um fato psíquico (empírico), que vai e vem. Mas o objeto do crer não vai e vem. Ele fica, permanece, como o pensamento pensado. Assim como o fundamento da filosofia está no pensamento, e não no ato de pensar, o fundamento da religião está no crido, no Numem, e não no ato de crer. Não no sentimento, mas no Numem.

Para uma análise das teorias de Husserl e também dos principais fenomenólogos - Otto, van der Leeuw, Eliade e Wach - cf. A.G. MENDONÇA, "Fenomenologia da experiência religiosa", Numem $\mathrm{n}^{\circ} 2$ (1999) 65-89.

${ }^{47}$ R. OTTO, Lo santo, op. cit., p. 148.

${ }^{48}$ R. OTTO, Lo santo, op. cit., p. 170. 
indefinibilidade que possibilita ao sagrado passar da transcendência à imanência e vice-versa, movimentar-se do limite do antropológico para o não-limite do absoluto" ${ }^{\prime 49}$. O sagrado é imanente e transcendente ao mesmo tempo. Por isso é que há necessidade da mediação, a religião, porque o sagrado e o profano não coincidem ${ }^{50}$. $\mathrm{O}$ fundamento da religião e do Numem, assim, não é algo negativizante - uma dependência -, mas positivo, a força do Numem. Esse sentimento religioso, todavia, não pode ser confundido com emoção ou algo parecido. Ele também se forma fora da pessoa. Não diz respeito a realidades psicológicas ou cognição. O sentimento do Numem não é o Numem em si, mas um efeito subjetivo concomitante da presença do Numem em mim, a sombra de outro sentimento fora de mim, o numinoso. É esse fora de mim que dá origem ao sentimento dentro de mim. O sentimento do numinoso é que forma esse sentimento de criatura, como seu concomitante ${ }^{51}$. A religião, assim, é aquilo que emerge do encontro do numinoso com o ser humano.

Otto lança mão de Kant - Crítica da razão pura - para referendar sua hipótese da religião enquanto fenômeno a priori: Certamente todo conhecimento começa com a experiência. Os objetos que ferem nossos sentidos é que despertam a faculdade de conhecer. Mas não por isso o conhecimento origina-se todo na experiência. Há um conhecimento fruto do empírico; mas há também conhecimento recebido por impressões, instigada nas impressões sensíveis.

O numinoso é desta espécie de conhecimento: começa com a experiência, mas não tem aí sua origem. Sua origem é a base cognoscitiva mais funda do espírito, do ser. Certamente essa base não é acionada antes de possuir experiências cósmicas e sensíveis, mas nestas e entre estas. Mas essa base não nasce das experiências. Por isso o sentimento religioso e seu objeto, o Numem, não dependem diretamente da predisposição psicológica ou cognitiva. A revelação acontece a priori, no fundo da alma. Ali nasce o sentimento religioso - que se manifesta exclusivamente nos sentimentos, como sentimento de presença de algo. O sentimento numinoso certamente aparece baixo certas condições, mas essas não são causas ou elementos componentes do Numem ${ }^{52}$. Deus nasce consigo mesmo. As impressões empíricas - sensíveis, racionais, morais - são estímulos para que o Deus desperte por si mesmo. Com o tempo os dois campos mesclados - experiência e base, ou então racional e irracional - vão purificando-se, até se-

\footnotetext{
${ }^{49}$ A.N. TERRIN, Antropologia e horizontes do sagrado, op. cit., p. 223.

${ }^{50}$ Para a distinção do sagrado e do profano, cf. o clássico de M. ELIADE, $O$ sagrado $e$ o profano, São Paulo: Martins Fontes, 2001, especialmente pp. 17-23 e, sobretudo, aquele que originalmente trabalhou essa distinção, É. DURKHEIM, As formas elementares da vida religiosa, op. cit., pp. 18-26.

${ }^{51}$ Cf. R. OTTO, Lo santo, op. cit., pp. 18-21.

${ }^{52}$ Cf. R. OTTO, Lo santo, op. cit., p. 162.
} 
parar-se, até o numinoso repelir o empírico. Daí brota a consciência de que o numinoso é elemento puro e a priori do conhecimento. Nada se assemelha a ele. Ele se junta e é veiculado pelos sentimentos sensíveis, mas não são transformações deles ${ }^{53}$. "O racional não é mais que o fundo, a borda, a trama" ${ }^{\prime \prime 4}$.

O Numem vai revelando-se aos poucos, cada vez com mais força, de acordo com o ritmo que se vai dando a conhecer no sentimento e no ânimo. Mas ele conserva sua incompreensibilidade nesse processo de revelar-se. E esse aspecto incompreensível vai-se estabelecendo cada vez com mais força. Quanto mais se revela, mas vai se apurando o Numem. Revelar-se não significa passar a ser compreensível conceitualmente. Conhecer e entender não são a mesma coisa. Manter a misteriosa penumbra do Numem não significa que não se pode conhecê-lo. Deus segue absconditus, mas não é ignotus ${ }^{55}$.

Por isso a conversão à religião nunca é a conversão pra valer. Não se pode dizer que, de repente, alguém passou a acreditar em Deus. Crer diz respeito a dar-se conta, a cair em si. O numinoso não se conhece, mas se revela. No cristianismo, especialmente no luteranismo, se dirá que o Espírito Santo é o desocultador do Numem ${ }^{56}$. O Espírito Santo é o desocultador dos sentimentos do coração. Certamente pode-se conhecer um Deus a posteriori, contemplando-o desde fora - suas catedrais, seus dogmas, seu governo, seus ritos. Assim como se observa uma casa e se imagina que dentro dela mora alguém. Mas se observado desde dentro - e este é o procedimento diferencial da teologia -, a priori, ninguém pode ver Deus, o Deus em si mesmo, sua essência. A Deus ninguém tem acesso a não ser pela revelação do Espírito Santo $^{57}$. O sagrado é uma experiência difícil; não se dá facilmente: com muita imanência e um pouco de transcendência, formula-se para o fiel.

O sagrado é a experiência do divino que fazemos neste mundo. Uma experiência difícil, ambígua, feita de uma mistura de imanência e de alguma pretensão de transcendência, de impulsos religiosos e de restrições éticas. $\mathrm{O}$

${ }^{53}$ Cf. R. OTTO, Lo santo, op. cit, pp. 148-153.

${ }^{54}$ R. OTTO, Lo santo, op. cit, p. 181.

${ }^{55}$ R. OTTO, Lo santo, op. cit, p. 173.

${ }^{56}$ M. LUTERO, Catecismo maior, São Leopoldo / Porto Alegre: Sinodal / Concórdia, 1983, p. 452: "Porque nem tu nem eu jamais poderíamos saber algo a respeito de Cristo ou crer nele e conseguir que seja nosso Senhor, se o Espírito não no-lo oferecesse e presenteasse ao coração, pela pregação do evangelho. A obra foi feita e está completada: pois Cristo nos obteve e conquistou o tesouro por sua paixão, morte, ressurreição, etc. Se, porém, a obra ficasse oculta, de forma que ninguém soubesse dela, seria vã e perdida. Ora, para que esse tesouro não ficasse sepulto, mas fosse aplicado e fruído, Deus enviou e fez proclamar a palavra, e nela nos deu o Espírito Santo, a fim de fazer-nos ver tal tesouro e redenção e torná-lo propriedade nossa. Santificar, por isso, outra coisa não é que conduzir ao SENHOR JESUS, para receber esse bem, ao que não poderíamos chegar por nós mesmos".

${ }^{57}$ Cf. R. OTTO, Lo santo, op. cit., p. 176. 
sagrado vive e convive com uma certa ambigüidade de expressão e de reconhecimento na nossa vida e isso se projeta como um jogo de luzes e de sombras também na realidade que nos envolve. Não temos condições de apanhá-lo e todavia sentimos que somos apanhados, somos incapazes de exprimi-lo e no entanto lhe sentimos a força intrínseca e o valor, não podemos reconhecê-lo definitivamente e apesar disso aceitamos os seus sinais e manifestações ${ }^{58}$.

Dizer que o Numem e a religião são fenômenos a priori não é imaginar algo fora da história, do tempo e do espaço. A religião se faz na história, "é produto da história, na medida em que a história, de um lado, desenvolve a 'predisposição' natural ao conhecimento do santo, e de outro lado é, em parte, 'manifestação' do santo. Religião natural em oposição a história não existe. Religião ingênita, muito menos" ${ }^{\prime \prime 59}$.

Dizer que o Numem e a religião são fenômenos a priori não é afirmar que sejam gerais, preexistentes em todos os lugares e em todos os espíritos, como se o sentimento religioso fosse natural. Dizer a priori é referir-se à capacidade de percepção estabelecida na pessoa para formar e sentir o numinoso. O numinoso não está na pessoa, mas nela está a capacidade de apreendê-lo. Como uma semente que se transforma na árvore: não há mudança real; não há ruptura. A árvore está latente na semente. Assim também a disposição latente no espírito humano move e desperta ao numinoso, de acordo com certos estímulos. É a expressão criativa do Numem em algumas pessoas que desperta o sentimento religioso em ou$\operatorname{tras}^{60}$. Qualificar o conhecimento do numinoso como a priori não significa dizer que é algo inato. Ele é a priori na medida em que todas as pessoas o podem ter; podem vir a tê-lo. "O santo não se ensina a si mesmo como tal, senão que é sentido desta maneira pelos outros" ${ }^{\prime 61}$. A fé irrompe espontânea por impressão, não ensinamento. Ela não nasce, ela é descoberta. Ela irrompe ${ }^{62}$.

Essa faculdade não é inata, não é geral nos seres humanos, mas se apresenta lá e cá. Esse conhecimento muito raramente desperta por si mesmo. Uns poucos o criam - como Jesus, Buda, Maomé, os profetas. A maioria das pessoas precisa de outras que o despertem. O que é geral é a disposição de recebê-los e julgá-los internamente. Não o produzem. Poucos profetas têm a capacidade especial de produzi-lo, aqueles que têm o espírito em forma de voz interior, que criam o Numem. A fé cristã diz que sobre o profeta há um terceiro - assim como sobre nós há o profeta. O profeta não se

\footnotetext{
${ }^{58}$ A.N. TERRIN, Antropologia e horizontes do sagrado, op. cit., p. 341.

${ }^{59}$ R. OTTO, Lo santo, op. cit., p. 217.

${ }^{60}$ Cf. R. OTTO, Lo santo, op. cit., p. 157.

${ }^{61}$ R. OTTO, Lo santo, op. cit., p. 198.

${ }^{62}$... E aqui as grandes teorias da religião vão se encontrando; as duas pontas da linha imaginária referida na introdução acima como que se encontram, anulando o ponto zero: "Porque a imagem, tal como a vida, não se aprende: Manifesta-se" (G. DURAND, As estruturas antropológicas do imaginário, op. cit., p. 411).
} 
deduz do primeiro; nem o terceiro não se deduz do Profeta. Ele é o não deduzível, Deus, ou o filho de Deus. Essa é a confissão do cristianismo: Cristo é o santo manifesto. Ele não é o objeto da santidade, mas a causa da santidade. Ele é a causa do Numem, não seu objeto. "Deus habita uma luz inacessível" (1Tm 6,16).

\section{3 - Os limites da Teologia e das Ciências Sociais no estudo da religião}

Os racionalistas que usam chapéus quadrados, sentados em salas quadradas, pensando pensamentos quadrados, deveriam experimentar um sombreiro.

Clifford Geertz ${ }^{63}$

A teologia precisa considerar o a priori transcendente e o a posteriori imanente no estudo da religião. Esse balanço nem sempre é possível, mas como situação ideal a teologia denuncia tanto o reducionismo imanente quanto o transcendente no estudo da religião.

A teologia denuncia o reducionismo psicológico da religião à emoção e à psique. A religião não é uma ilusão ou uma compensação da qual o ser humano lança mão. Não basta descrever o ambiente religioso e suas conseqüências positivas para a vida de pessoas que estariam numa condição desfavorável. A teologia insiste em distinguir o impacto da presença de Deus nas religiões, daquela simples excitação exacerbada determinada por performances psicologizantes. Insiste também em dizer que não basta descrever a eficácia da performance religiosa - geralmente aquelas mais extravagantes, secretas e manipuladoras! Não se podem esquecer as idéias religiosas e estudar na religião apenas as manifestações emocionais, sobretudo os interessantes e pitorescos estados místicos, êxtases, manifestações corporais e a excitação emocional - as pessoas que participam de uma religião não apenas vivenciam, sentem, experimentam Deus, mas também pensam a religião, entendem, refletem, analisam. Por isso a teologia reivindica que ao lado da observação e descrição empírica o estudo da religião precisa perguntar pelos conteúdos e verdades da religião ${ }^{64}$.

A teologia denuncia o reducionismo sociológico da religião que a associa unicamente à ideologia que dá coesão social, e o reducionismo antropológico-filosófico da religião, que a associa unicamente a sentido de vida. As

\footnotetext{
${ }^{63}$ Em Antropologia interpretativa, apud A.N. TERRIN, Antropologia e horizontes do sagrado, op. cit., p. 55.

${ }^{64}$ E. TROELTSCH, El carácter absoluto del cristianismo, op. cit, p. 200.
} 
inúmeras teses da precariedade ${ }^{65}$, sempre uma tentação, também para a teologia, não dão conta de explicar o sucesso de determinadas religiões, assim como as especificidades performáticas não dão conta de explicar o fracasso de outras. A sociologia certamente pode dizer que a religião dá respostas à aflição humana, mas não é essa a sua origem; daí que também não é essa sua natureza. Ligar o sucesso do pentecostalismo ou o fracasso do protestantismo clássico unicamente ou sobretudo aos processos de urbanização, ao individualismo contemporâneo, à suposta manipulação ou condicionamentos psicológicos, à força da mídia e a volta ao arcaico, entre outros, acaba por tornar o divino refém da sociedade e suas ciências. Eficácia e sentido para a vida certamente são manifestação da religião, mas não é o seu específico, aquilo que a distingue de todos os outros fenômenos, a sua essência divina. "A interpretação da religião como um fenômeno social não esgota as possibilidades de explicá-la. Embora as teorias sociológicas da religião pareçam se apresentar com certa exclusividade, elas são complementares entre si - apesar de certas contradições - e mesmo em conjunto não conseguem dizer tudo que pode ser dito sobre religião. Explicam o que a religião faz, mas explicam muito menos o que ela $\mathrm{e}^{\prime \prime 66}$. A teologia reconhece e afirma que o que distingue a religião de qualquer outra manifestação social ou humana é a sensação de presença de Deus ${ }^{67}$; "sensação da presença do divino através de acontecimentos e realidades concretos e finitos" ${ }^{\prime 68}$, e se associa à sociologia que vê Deus agindo nos fiéis que "já simplesmente ao entrar na congregação sentiram 'uma coisa diferente', ou que foram 'tomados pela presença de Deus'"169. O estudo da religião precisa preservar "a sensação religiosa da presença tanto da evaporação em idéias meramente abstratas quanto de uma dissolução em todo tipo de contingências e condicionamentos puramente humanos ${ }^{\prime \prime 70}$.

\footnotetext{
${ }^{65}$ Já é lugar-comum dizer que a religião é uma compensação a toda espécie de precariedade. A religião seria um paliativo - sobretudo as religiões mais populares como umbanda e pentecostalismo, que seriam 'respostas à aflição', situando "a temática religiosa, em primeira instância, nos empenhos individuais e coletivos pela auto-realização por meio da produção de sentido" (J. BITTENCOURT FILHO, Matriz religiosa brasileira, Petrópolis / Rio de Janeiro: Vozes / Koinonia 2003, p. 29). A função da religião seria apenas colaborar para a auto-realização e para tornar sofrível o sofrimento. As religiões "oferecem 'sentidos para a vida', alternativas religiosas para 'tornar sofrível o sofrimento', fabricação de partilhas de significados que servem para renovar a esperança” (R. REYS NOVAES, "Pentecostalismo, política, mídia e favela", in V.V. VALLA (org.), Religião e cultura popular, Rio de Janeiro: DP\&S, 2001, pp. 41-74, aqui pp. 64s).

${ }_{66}$ A. DROOGERS, Religiosidade popular luterana, São Leopoldo: Sinodal, 1984, p. 71.

${ }^{67}$ Cf. E. TROELTSCH, El carácter absoluto del cristianismo, op. cit., pp. 198-199.

${ }^{68}$ E. TROELTSCH, El carácter absoluto del cristianismo, op. cit., p. 223-224.

${ }^{69}$ C.L. MARIZ, "Libertação e ética", in A. ANTONIAZZI (org.), Nem anjos, nem demônios, Petrópolis: Vozes, 1994, pp. 204-224, aqui p. 213. Estudando a cura do alcoolismo enquanto 'libertação do mal' no pentecostalismo, Mariz mostra que ao lado e apesar da importância do papel do grupo comunitário no processo de cura, os fiéis parecem destacar como decisivo sua experiência com Deus.

${ }^{70}$ E. TROELTSCH, El carácter absoluto del cristianismo, op. cit., pp. 223-224.
} 
É cegueira ideológica ou falta de informação científica explicar o fenômeno religioso exclusivamente a partir do aspecto etnológico, psicológico, sociológico, histórico, fenomenológico, filosófico ou o que o valha, enfim, imanente. É, fora de dúvida, birra cristã desqualificá-lo como mera manifestação antropocêntrica ou até demonizá-lo. A religião inicia consigo própria, ela "é uma categoria puramente a priori". (...) Religião não se deixa construir ou inventar, mas apenas interpretar e analisar criticamente como algo que existe. (...) O fenômeno religioso, multifacetado e inextinguível, universal e atemporal, é efeito do fato de que Deus está por aí, que ele rumoreja ${ }^{71}$.

Girar em torno do fenômeno religioso por meio da fisiologia, da psicologia, da sociologia, da economia, da lingüística, da arte etc. significa traí-lo e deixar escapar justamente o quid único e irredutível que ele contém: seu caráter sagrado. Certamente não existem fenômenos religiosos 'puros'; não existem fenômenos única e exclusivamente religiosos. Sendo coisa humana, a religião é por isso mesmo também um fato social, lingüístico e econômico - não é concebível o homem fora da linguagem e da vida coletiva. Mas seria inócuo explicar a religião por uma dessas funções fundamentais que definem, em última análise, o homem ${ }^{72}$.

A teologia denuncia o próprio reducionismo teológico que não associa à religião os condicionamentos sociais, psicológicos e antropológicos. Enquanto discurso que pensa-o-ser-humano-em-relação-a-Deus, a teologia reconhece que a sua contribuição, o dado Transcendência, é pertinente no estudo da religião, e não pode ser ignorado pelas outras ciências; no mesmo momento, no entanto, a teologia reconhece que a religião não se reduz a essa pertinência, e que as outras ciências certamente têm pertinências decisivas. Da mesma forma, enquanto criação humana a teologia reconhece seu limite, e reconhece que sua palavra está muitas vezes ancorada em pressupostos para além da teologia, como condicionamentos ideológicos, classistas etc. - como de resto também acontece com as ciências sociais.

Por isso a teologia não rejeita as contribuições das outras ciências que estudam a religião. Em certa medida até as exige. A teologia reconhece que "as opiniões teológicas têm suas raízes nas relações entre a vida religiosa e as condições culturais e políticas. (...) A vida religiosa é tão entrelaçada com as circunstâncias sociais que a formulação da teologia é necessariamente condicionada por elas ${ }^{\prime 73}$. Da mesma forma, a teologia e o crente

\footnotetext{
${ }^{71}$ A. BAESKE, "Testemunhando a Jesus Cristo em nossos dias", Estudos Teológicos 42 (2002) 85-107, aqui p. 89.

${ }^{72}$ M. ELIADE, apud A. TERRIN, O sagrado off limits, São Paulo: Loyola, 1988, p. 39. Como prefere o próprio autor, à p. 41, o sagrado é off limits, uma afirmação contra "quem crê que pode tratá-lo como um brinquedo de desmontar ou como uma peça de museu que pode ser abandonada em qualquer canto, porque não há mais compradores ou não é mais comercializável".

${ }^{73}$ H.R. NIEBUHR, As origens sociais das denominações cristãs, São Paulo / São Bernardo do Campo: ASTE / IEPG, 1992, p. 18.
} 
reconhecem a realidade cultural de Deus, sua manifestação ritual, psicológica etc. "Incontestavelmente, uma parte da realidade-Deus é um real que depende de um discurso psicológico, sociológico etc., por ser usado por homens ${ }^{\prime \prime 74}$. A teologia também reconhece, logicamente, a exemplo de outras ciências, que não existem fenômenos puros ou exclusivamente religi$\operatorname{osos}^{75}$. Certamente a teologia não exige das ciências humanas aquilo que elas não querem ou não podem fazer.

As ciências humanas se perguntam aquilo que, no homem, explica que ele tenha deuses: motivações psicológicas, interesses ou modelos sociológicos, simbolização última, etc. Nessa perspectiva, evidentemente não se pede um 'outro lugar', metafísico ou revelado, para decidir a respeito da existência de Deus. Deus é visto como uma realidade antropológica, projeção psicológica, produção sociológica, acidente de linguagem etc. Dentro dessa perspectiva, portanto, é que se pergunta sobre esse processo, como e por que o homem fornece e constrói para si deuses: um Deus, tal Deus ${ }^{76}$.

Além disso, a teologia reconhece nas ciências do imanente um necessário trabalho de poda $7^{77}$ epistemológica da teologia; elas provocam a teologia a justificar seu discurso com argumentos racionais críveis, evitando e vigiando discursos teológicos fáceis e espiritualizantes. As ciências humanas colaboram com a teologia no sentido de desmascarar religiões e ritos que se apegam demasiadamente a realidades humanas, e dessa forma exercem o papel de vigias epistemológicas, corrigindo e purificando a percepção de Deus. Por tudo isso, a teologia não teme as perguntas das ciências humanas. Até se orgulha de defender um discurso atacado, medido, vigiado.

Não obstante esse reconhecimento, a teologia não pode furtar-se à tarefa específica de estudar aquilo que Deus anda fazendo apesar dos processos psicológicos e sociológicos em jogo na religião - no que de resto as outras ciências também concordam. E aí a teologia vê Deus agindo em qualquer experiência ou fenômeno religioso. A teologia insiste em dizer que aspectos imanentes não dão conta, sozinhos, de explicar algo que tem motivações, conteúdo e fins sobretudo transcendentes. A tarefa da teologia seria justamente garantir e preservar o aspecto apriorístico da religião, reconhecendo-a como forma organizada de uma comunidade corresponder ao sagrado, à divindade.

Religião diz respeito a FÉ, ao reconhecimento da irredutível iniciativa divina no processo de sua constituição. Fé inclui emoção, razão e condicionamentos imanentes de toda ordem, mas nada disso produz fé. A fé abar-

${ }^{74}$ A. GESCHÉ, Deus, São Paulo: Paulinas, 2003, p. 37.

${ }^{75}$ Cf. M. ELIADE, Tratado de história das religiões, Lisboa: Cosmos, 1970, p. 17.

${ }^{76}$ A. GESCHÉ, Deus, op. cit., p. 36.

${ }^{77}$ A. GESCHÉ, Deus, op. cit., p. 38. 
ca esses parâmetros humanos e os sujeita ao poder divino ${ }^{78}$; a fé abre o fiel à Presença de Deus que toma conta dele. Nesse lugar da fé os estudos da religião chegam ao limite do discernível e se entregam à quase pura contemplação do divino. E aqui a teologia não pode abrir mão de constituirse enquanto campo do saber que acompanha o fiel até esta última fronteira do conhecimento da religião, indo mais além do que qualquer outra ciên$\mathrm{cia}^{79}$.

Paradoxalmente, é justamente no elemento da fé que talvez esteja a grande chave para que a teologia construa um método de estudo da religião que relativize os reducionismos e associe o aspecto imanente ao transcendente. Certamente não é possível reduzir os estudos da religião à radicalidade do a priori ottoniano - como dito acima, ele se coloca aqui como uma espécie de ação afirmativa diante da profusão de estudos a posteriori. O ideal seria uma teoria que chegasse ao razoável, conjugando o imanente e o transcendente, o racional e o irracional - ou então se contentar com diferentes e independentes pertinências.

Embora o sentimento religioso - e suas expressões - não constitua o cerne da religião, sendo apenas o reflexo da Revelação, a teologia reconhece que Deus opera através do humano - basta lembrar que o cerne da Revelação cristã é justamente a encarnação do divino no humano. Quando a teologia anuncia que Deus viceja, que Deus vem vindo, ela identifica e reconhece os caminhos por onde Deus vem, agenciando a Revelação. A teoria do trajeto antropológico de Durand pode colaborar, transformando-se em teoria do trajeto teológico: a fé, o crer, é sempre um movimento duplo simultâneo, de Deus para o ser humano e o mundo, e, depois, deste para Deus. Essa fé, com todo o aparato que ela compreende, inclusive aqueles referidos pelas ciências do imanente, seria o élan que liga o transcendente e o imanente, agenciando a religião - que tem preservado seu o aspecto divino, totalmente a priori, e preservada também a autonomia humana e cultural, que agencia esse a priori. Dessa forma a teologia estaria diante de uma dinâmica profundamente protestante de entender a revelação de Deus e a constituição da religião:

no âmago da doutrina protestante há lugar para o que chamamos de 'estrutura divina da realidade'. Esse lugar é a fé. O julgamento divino, apesar de sua transcendência e independência, só tem sentido e poder quando apropriado pela fé, pela Igreja e pelo indivíduo. A fé é sempre humana. Não vem do ser humano, mas é nele que se efetiva. Na medida em que se

\footnotetext{
${ }^{78}$ P. TILLICH, Teologia sistemática, São Leopoldo: Sinodal, 1981, p. 487.

${ }^{79}$ A. GESCHÉ, Deus, op. cit., p. 37, nota 49, tem uma comparação elucidativa: seria como se a Estética tivesse que abrir mão de sua ultimacidade sobre a crítica da Arte e referendar os discursos da antropologia, da semiótica ou da psicologia, embora estes sejam legítimos.
} 
manifesta concretamente na comunidade ou nos indivíduos, comunidade e indivíduos passam a ser portadores da graça. A fé é criada pela audição da 'Palavra'. A Palavra é dita de fora, para nós. Mas, ao ser recebida já não é apenas transcendente. Torna-se também imanente, e cria a estrutura divina da realidade. Assim, surge a fé enquanto poder formativo da vida pessoal e da comunidade ${ }^{80}$.

O a priori da fé cresce a partir da penetração na realidade $e^{81}$. Também aqui se pode referir a assimetria entre princípio e forma que funda o protestantismo: é a união do princípio com a forma que faz emergir a realidade da Graça, a presença de Deus. Desta forma pode-se dizer que embora a religião não nasça na sociedade, cresce com ela. E aí a complexidade da religião abre-se em três movimentos: Deus de um lado, o ser humano e o mundo de outro; no meio, a fé na Revelação, aquilo que dá movimento. Ou seja: se ao estudar a religião a teologia ficar presa no profundo a priori, ela se perde na Indiscernibilidade. Ao render-se ao a posteriori, ela morre. Metodologicamente o estudo das religiões pode partir tanto do ser humano quanto de Deus; o segredo está não de um lado ou outro, mas justamente no meio, no movimento. Imprescindível é que os estudos conjuguem sempre os dois $\operatorname{lados}^{82}$.

Aqui a teologia reencontra-se com Durand e seu instigante reconhecimento de que a finalidade de toda imaginação ou simbolização, também a religião, é agenciar a "mediação do Eterno no temporal" ${ }^{33}$. A imaginação, em todas as suas modulações, é uma negação do desequilíbrio entre o derradeiro e o Último. Justamente aí, depois de reconhecer os outros benefícios da imaginação ou simbolização - "restabelecer o equilíbrio vital comprometido pela noção da morte; (...) restabelecer o equilíbrio psicossocial; (...); [e estabelecer] o equilibrio antropológico" 84 -, Durand cairá inevitavelmente na finalidade última da imaginação, o estabelecimento da Teofania enquanto equilibro entre o Eterno e o Temporal: "Na irremediável ruptura entre a fugacidade da imagem e a perenidade do sentido que o símbolo constitui, precipita-se a totalidade da cultura humana, como uma mediação perpétua entre a Esperança dos homens e sua condição temporal" ${ }^{\prime \prime 5}$.

É esta possibilidade de manifestação do Eterno, aliás, que permite à teologia regozijar-se na tarefa de testemunhar a revelação de Deus no lugar

\footnotetext{
${ }^{80}$ P. TILLICH, A era protestante, São Paulo: Traço a Traço, 1992, p. 227.

${ }^{81}$ P. TILLICH, A era protestante, op. cit., p. 233.

82 A. DROOGERS, Religiosidade popular luterana, op. cit., p. 71, sugere a instigante metáfora-esquema do triângulo para compor uma teoria híbrida de estudo da religião: $a$ religião seria um triângulo que tem como vértices a teologia, a sociologia e a fé. Apenas a partir do conjunto desses três ângulos é que a religião se revela a quem pesquisa.

${ }^{83}$ G. DURAND, A imaginação simbólica, São Paulo: Cultrix, [s.d.], p. 110.

${ }^{84}$ G. DURAND, A imaginação simbólica, op. cit., p. 100.

${ }^{85}$ G. DURAND, A imaginação simbólica, op. cit., p. 110.
} 
natal da Cruz, e, ao mesmo tempo, admirar-se silenciosa diante da presença de Deus nas significações religiosas não cristãs do imaginário religioso brasileiro. Enquanto discurso sobre a metáfora do divino, estudiosa da representação da Revelação, a teologia preserva uma abertura necessária para o Inusitado que pode sempre lhe surpreender.

De uma forma ou outra, denomine-se esse Inusitado de Esperança, Eterno, Teofania ou Divino, aqui as ciências do imanente parecem chegar ao limite, e nesse momento entra em questão a teologia e sua interpretação da religião, com toda a autoridade do saber acumulado e da sensibilidade exercitada justamente ali onde a religião acontece, perto do fiel, pensando o ser humano e o mundo em relação a Deus, ainda que seja no limite e à margem de outros saberes, como aquela reserva atenta à Revelação MaisQue-Profunda - e seus suaves ruídos.

\section{Conclusão}

Considerando os estudos sobre o imaginário religioso brasileiro, a teologia tem um papel muito importante a desempenhar, seja pelo simples fato da importância que a fé e a crença no estamento divino da cultura e das religiões têm no Brasil, seja devido a uma espécie de moratória que as outras ciências que estudam a religião parecem ter declarado à teologia ${ }^{86}$. Enquanto a Sociologia e a Antropologia analisam as funções e o papel da religião, mais interessadas nas suas estruturas simbólicas, a teologia, sem desconsiderar essas pertinências, lança-se ou abre-se para a análise dos vestígios do divino.

Se a teologia insiste em estudar a religião considerando a pertinência da Revelação e da Transcendência, não o faz crendo que ela, sozinha, dá conta de explicar o fenômeno religioso, mas a coloca como numa ação afirmativa teórica, visando relativizar o peso imanente dos estudos da religião. Nessa radicalidade, embora afirme que a religião é agenciada no plano imanente, a teologia insiste em dizer que ela está carregada de divino. A significação religiosa do imaginário existe e se afirma em relação às significações soci-

\footnotetext{
${ }^{86}$ Para uma análise da sociologia da religião no Brasil, analisando a recepção dos clássicos e constando a ignorância do dado religião nas pesquisas sobre a sociedade brasileira, cf. R. ALVES, O suspiro dos oprimidos, op. cit., o cap. "a ciranda dos deuses", às pp. 101-143. Para uma análise da sociologia do protestantismo, de caráter estritamente bibliográfico, cf. W. CÉSAR, Para uma sociologia do protestantismo brasileiro, Petrópolis: Vozes, 1973. Para uma análise completa dos clássicos da sociologia da religião, contemplando Marx, Durkheim, Weber, Marcel Mauss, Evans-Pritchard, Maurice Leenhardt, Bourdieu, Clifford Geertz, Peter Berger e Danièle Hervieu-Léger, cf. F. TEIXEIRA, Sociologia da religião, op. cit. - observem-se as ausências de Mircea Eliade e Rudolf Otto.
} 
ais, psicossociais e antropológicas, mas não tem nelas sua origem. No limite da ação afirmativa, a teologia diz que a religião tem um fundamento e uma origem a priori, totalmente transcendente, e que o imaginário religioso é obra de Deus, locus de sua manifestação. Os alicerces do imaginário religioso são, paradoxalmente, sustentados pelo Alto ${ }^{87}$.

Como não ter Deus? Com Deus existindo, tudo dá esperança: sempre um milagre é possível, o mundo se resolve. Mas, se não tem Deus, há-de a gente perdido no vai-vém, e a vida é burra. É o aberto perigo das grandes e pequenas horas, não se podendo facilitar - é todos contra os acasos. Tendo Deus, é menos grave se descuidar um pouquinho, pois, no fim dá certo. Mas se não tem Deus, então, a gente não tem licença de coisa nenhuma. Porque existe dor. E a vida do homem está presa encantoada - erra rumo, dá em aleijões ${ }^{88}$.

Adilson Schultz, Pastor na Igreja Evangélica de Confissão Luterana no Brasil, é mestre (2000) e doutor (2005) em teologia, pela Escola Superior de Teologia de São Leopoldo, RS, tendo defendido a tese doutoral intitulada Deus está presente - o diabo está no meio: as estruturas teológicas do imaginário religioso brasileiro. Atualmente é professor na PUCMinas e na Faculdade Jesuíta de Filosofia e Teologia (FAJE), e assessor do CEBI-MG.

Endereço: Rua Palmira, 493/5 - Serra 30220-110 Belo Horizonte - MG e-mail: adilson@luteranos.com.br

${ }^{87}$ A. GESCHÉ, $O$ ser humano, São Paulo: Paulinas, 2003, p. 7.

${ }^{88}$ Riobaldo, em J. GUIMARÃES ROSA, Grande Sertão: veredas, 35a ed., Rio de Janeiro: Nova Fronteira, 1988, p. 48. 